\title{
Rio Tinto's framework for evaluating risks from low sulfur waste rock
}

\author{
R Green Rio Tinto, Australia \\ C Linklater SRK Consulting (Australasia) Pty Ltd, Australia \\ S Lee Rio Tinto, Australia \\ L Terrusi Rio Tinto, Australia \\ K Glasson Rio Tinto, Australia
}

\begin{abstract}
There is an increasing need in mine closure studies for a toolbox of procedures designed specifically for application to low sulfur waste types - to help build confidence in the generally accepted premise that these wastes have a low risk profile. Historically, mine waste characterisation efforts have focused on materials with elevated sulfur. This is warranted due to the greater risk associated with acid and metalliferous drainage from potentially acid forming wastes. Test procedures for materials with elevated sulfur are well established. Regarding low sulfur and non-acid forming materials, the toolbox of geochemical characterisation procedures can vary significantly depending on personal preference and jurisdictions.

The framework for geochemical characterisation of low sulfur waste materials at Rio Tinto's Pilbara Mines will be presented. This framework involves phased testing, starting initially with a wide range of samples from different locations and depths. Progressively more detailed tests are undertaken, depending on the waste storage conditions and unresolved issues or uncertainty. Risk assessments are undertaken in conjunction with geochemical testing to evaluate risks posed by waste material properties and tonnages. There is no 'one size fits all' test method for low sulfur waste material. This Rio Tinto framework provides flexibility by using a combination of test methods to understand and, if necessary, appropriately manage any risks identified.
\end{abstract}

Keywords: neutral mine drainage, geochemistry, mineral waste management

\section{Introduction}

\subsection{Neutral mine drainage}

Geochemical characterisation of waste material is an essential component for any mine operation and the associated mine closure plan. Waste rock, tailings facilities, and pit voids containing chemically reactive mineral waste may remain at mine closure and it is important to understand potential long-term contaminant release. Mine drainage associated with these landforms can manifest as acidic, neutral or saline drainage, with potential for elevated metals and/or sulfate concentrations.

Significant effort is often dedicated towards understanding the potential for acid and metalliferous drainage (AMD) from waste material containing elevated concentrations of sulfur. This is justified due to the significantly greater risk posed by these materials, however, project scoping should not exclude studies necessary to understand the risk from neutral mine drainage (NMD).

There are three principle causes of NMD (Stantec Consulting Ltd. 2004):

1. Near neutral pH metal leachate drainage derived from non-sulfide minerals.

2. Leaching of metals due to metal sulfide oxidation and subsequent neutralisation of the acidity. 
3. Metal leaching from subaqueous disposal of potentially acid forming (PAF) waste, which previously had been subjected to weathering and release of oxidation products.

Several chemical compounds (e.g. sulfates or organic matter) do not require acidic conditions to maintain concentrations elevated above environmental guideline levels and can therefore be important in generating neutral $\mathrm{pH}$ drainage (e.g. if they have high solubilities). NMD can result from different processes but neutral $\mathrm{pH}$ drainage does not necessarily prevent metal leaching occurring in sufficient quantities to cause negative impacts. While the solubility of aluminium, iron and copper is greatly reduced in neutral $\mathrm{pH}$ drainage, elements such as antimony, arsenic, cadmium, molybdenum, selenium, sulfate, and zinc remain relatively soluble and can occur in elevated concentrations. Unlike AMD, neutral pH metal leaching is generally only a concern if there is little downstream dilution and/or discharge impacts a sensitive receptor.

\subsection{Mineral waste at Rio Tinto}

Mineral waste includes the waste rock and tailings that are produced during mining operations as well as the pit voids that remain upon completion of mining. Rio Tinto Iron Ore (Rio Tinto) has 16 mining operations in the Pilbara region of Western Australia (Figure 1). Extensive strategies and plans have been developed for the effective management of mineral wastes. Wastes are managed utilising a risk-based approach with strategies implemented to minimise the likelihood for health, safety, and environment impacts to occur.

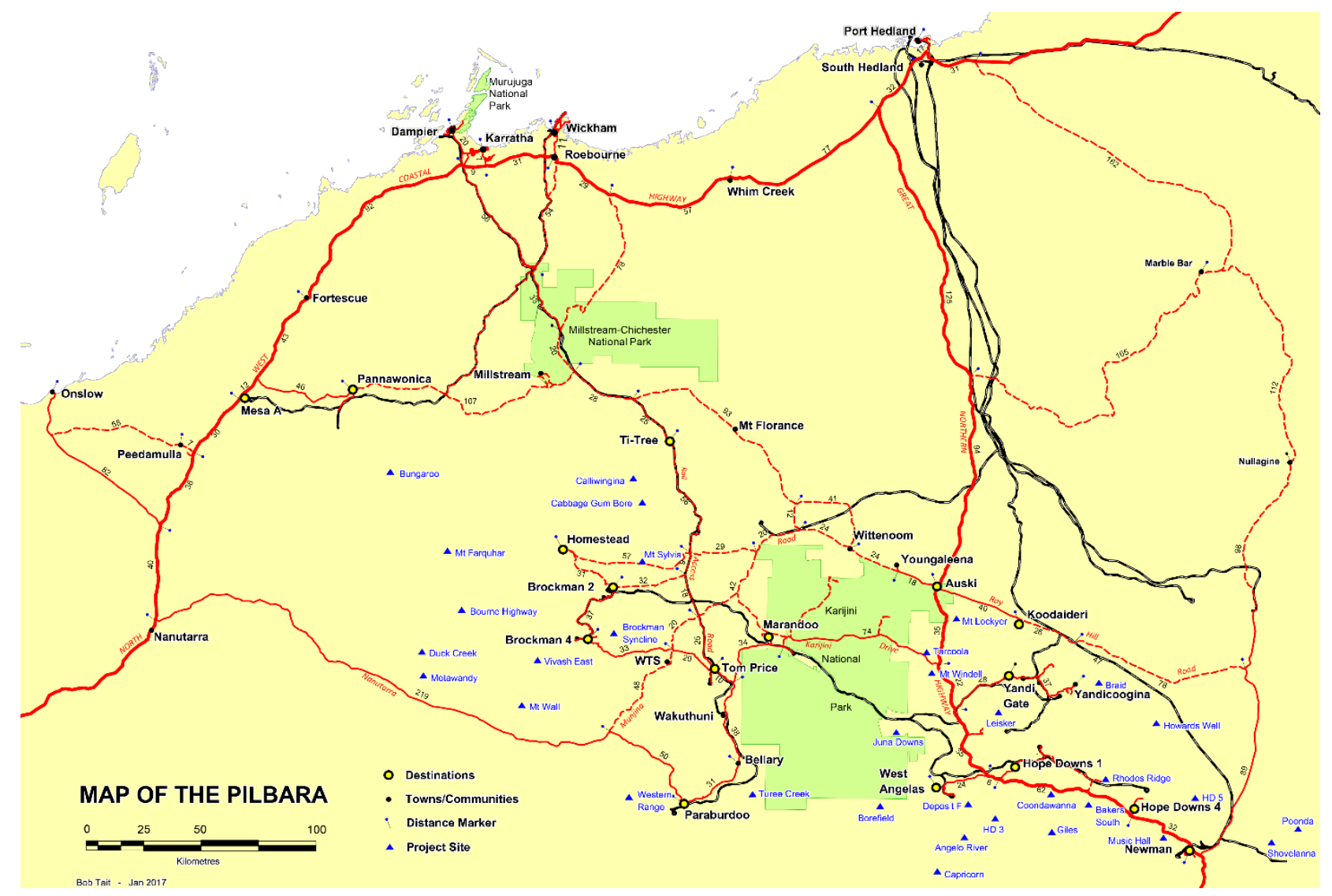

Figure 1 Location of Rio Tinto mines in the Pilbara region of Western Australia

In Rio Tinto, reactive mineral wastes are assessed across nine areas: acidic drainage, neutral drainage, salinity, nitrogen compounds (e.g. blasting agents), asbestos, organics (e.g. from shale or lignite), alkaline drainage, radioactivity, and cyanide.

Risk assessments that have been carried out for Rio Tinto's Pilbara operations and projects have identified that the highest level of environmental risk is associated with only a few stratigraphic units, all of which contain pyrite, and consequently, have the potential to cause acidic drainage. However, mineral waste 
management and assessment at Rio Tinto is continually ongoing. Initial assessments are undertaken during exploration and the acquisition of drillhole samples, and further assessments take place as projects develop into active operations and beyond. Assessment data are utilised to identify problematic stratigraphic units and those materials that will require additional characterisation testing.

\subsection{Stratigraphy of the Hamersley Group}

Rio Tinto's Pilbara operations extract ore from Detrital and Channel Iron Deposits, as well as from the Brockman iron formation and the Marra Mamba iron formation of the Hamersley Group (Figure 2). Associated waste from adjacent lithologies can be extracted during the open pit mining process.

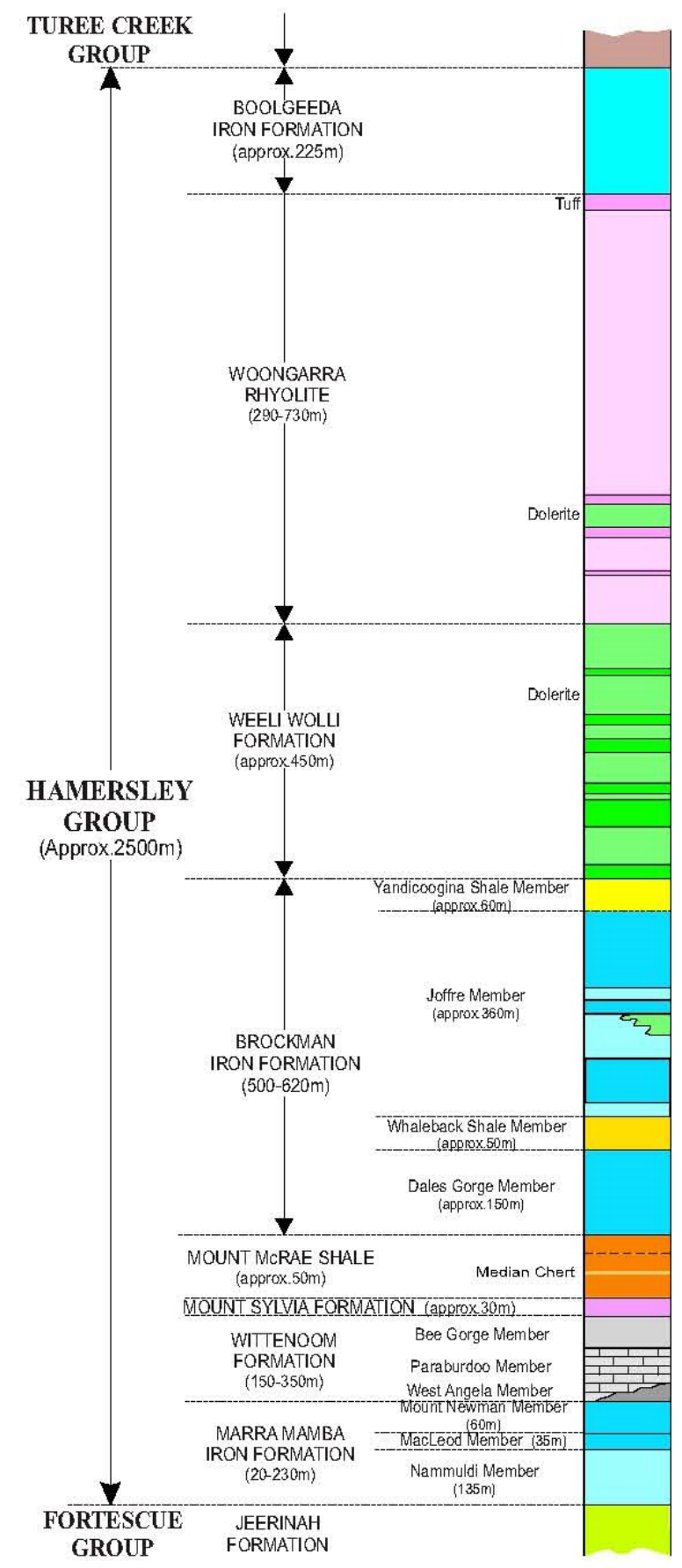

Figure 2 Stratigraphic column of the Hamersley Group 
The consistency of the stratigraphic sequence across the entire Pilbara region allows data for a particular stratigraphic unit at one site to be used to supplement data for that unit at another site. This is indicated in Figure 3, where average sulfur content is shown to be low in many waste types across various locations, while sulfur content is consistently elevated in unoxidised Mount McRae Shale (commonly referred to as black shale). Figure 4 presents data on measured acid neutralising capacity (ANC) collected for rock samples across the Pilbara region and grouped together by lithology. The ANC tends to be consistently low for most waste types (with the majority $<10 \mathrm{~kg} \mathrm{H}_{2} \mathrm{SO}_{4}$ /tonne). Conversely, ANC can be significantly greater in Wittenoom formation dolomite and detrital calcrete.
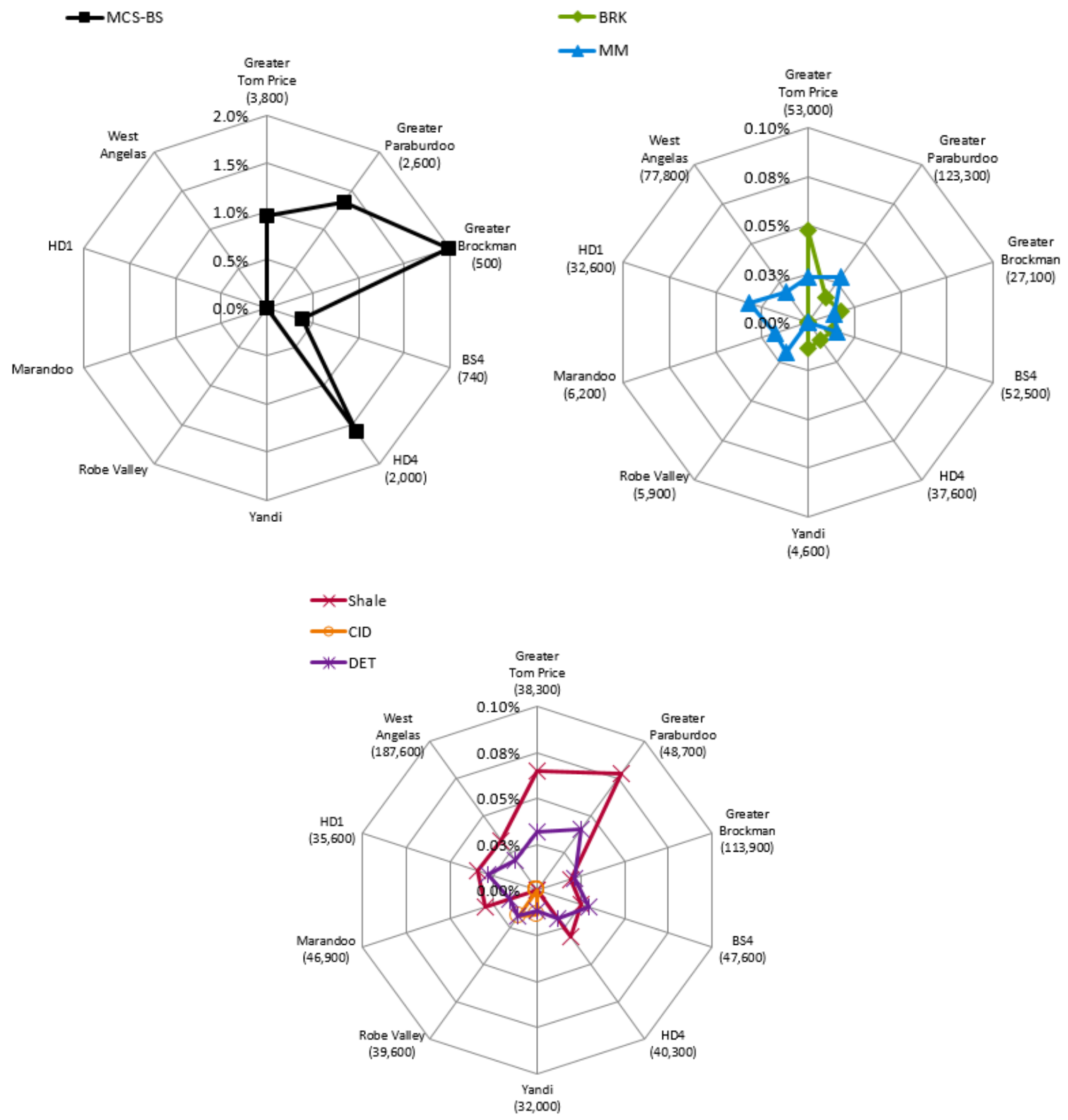

Figure 3 Average total sulfur content of drillhole waste samples from Rio Tinto mine sites (both in-pit and out of pit). The number of samples analysed are represented next to the site name. MCSBS = unoxidised black Mount McRae Shale (encountered at some sites); BRK = Brockman iron formation; $\mathrm{MM}=$ Marra Mamba iron formation; $\mathrm{DET}=$ Detrital; $\mathrm{CID}=$ channel iron deposits 

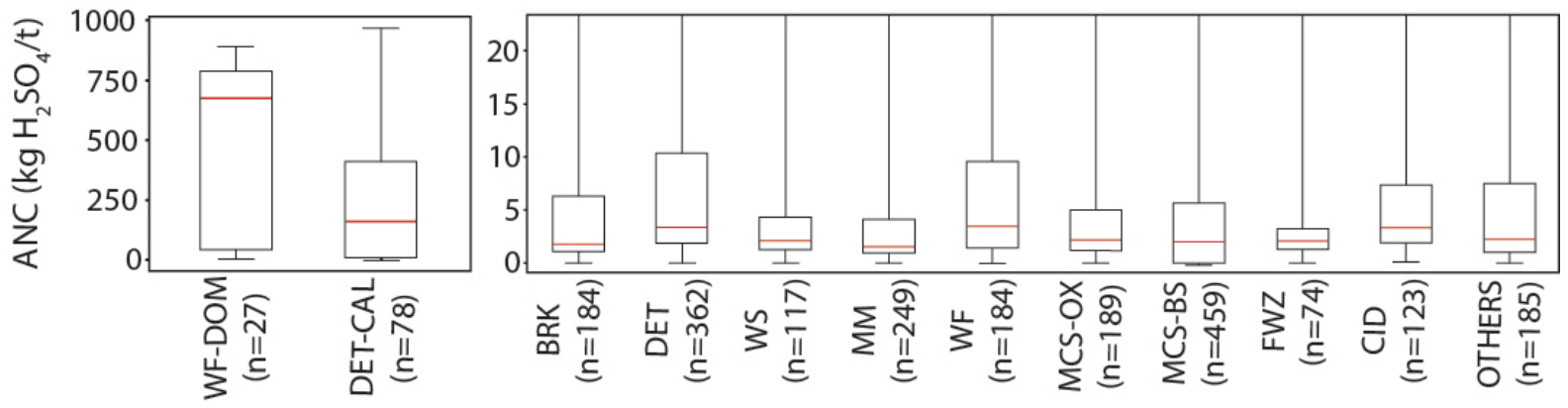

Lithology

Figure 4 Acid neutralising capacity (ANC) variation (5th percentile, 25th percentile, median, 75th percentile and 95th percentile) in different lithologies (showing the number of samples analysed). WF-DOM = dolomite in Wittenoom formation; DET-CAL = calcretes in detritals; BRK = Brockman iron formation; $\mathrm{DET}=$ detrital; $\mathrm{WS}=$ Whaleback shale member; $\mathrm{MM}=$ Marra Mamba iron formation; WF = Wittenoom formation; MCS-Ox = oxidised Mount McRae shale; MCS-BS = unoxidised black Mount McRae shale; FWZ = footwall zone; CID = channel iron deposits

The consistency in geochemical data does not necessarily preclude the acquisition of site-specific data. At any site, it is essential that sufficient data are acquired to confirm that a given stratigraphic unit has the same characteristics at that site as at other sites where data has already been acquired.

\section{$2 \quad$ Neutral mine drainage test framework}

Extensive work is undertaken by Rio Tinto in relation to the management of mineral waste through all stages of the mining lifecycle: from exploration, through operations, to closure. A variety of tests are undertaken to characterise the wastes, including assaying, acid base accounting, liquid extracts, additional static, and kinetic tests. A large database of such test results has been acquired for the region (Figures 3 and 4). The NMD test framework is represented in Figure 5 and described in the subsequent sections.

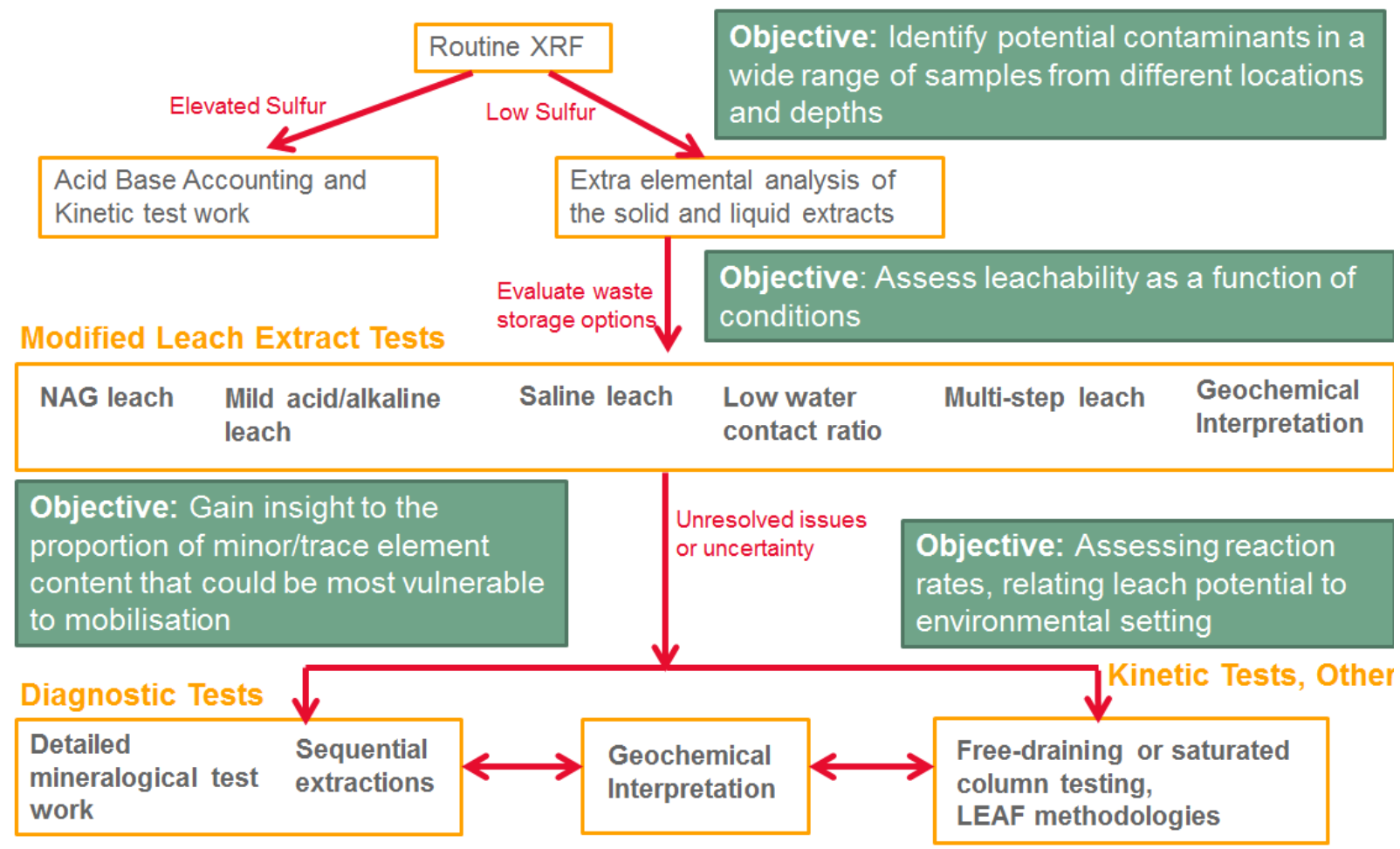

Figure 5 Neutral mine drainage testing framework 


\subsection{Routine analysis}

During exploration, many drillhole samples were obtained from a wide variety of locations and lithologies. Regarding NMD assessments, it is important to examine this data to assess spatial variability and ensure that samples selected for detailed geochemical testing are representative of the bulk of the waste to be extracted, or if not representative of the bulk, are representative of specific but relevant aspects of minor waste types.

The samples are assayed over set intervals (typically $2 \mathrm{~m}$ ) to determine elemental composition. This assaying provides important characterisation data for both ore and waste. Drillhole samples are regularly assayed for the following elements: $\mathrm{Al}, \mathrm{As}, \mathrm{Ba}, \mathrm{Cl}, \mathrm{Co}, \mathrm{Cr}, \mathrm{Cu}, \mathrm{Ca}, \mathrm{Fe}, \mathrm{Pb}, \mathrm{Mg}, \mathrm{Mn}, \mathrm{Ni}, \mathrm{P}, \mathrm{K}, \mathrm{Na}, \mathrm{Si}, \mathrm{Sr}, \mathrm{S}, \mathrm{Sn}, \mathrm{Ti}$, $\mathrm{V}, \mathrm{Zn}$, and $\mathrm{Zr}$.

The most problematic material identified is material containing sulfur, particularly in the form of sulfide minerals. For each stratigraphic unit that contains sulfide sulfur, a conservative cutoff limit is identified above which the material is specially managed in bulk. The two cutoff limits which have been derived are 0.1 and $0.3 \%$ total sulfur. However, other conservative management criteria have also been adopted at some sites where, e.g. all black shale regardless of sulfur concentration is specially managed.

The chemical assays of drillhole samples combined with an assessment of potential tonnages of different lithologies in the mining model are used to generate an AMD risk assessment (Green \& Borden 2011). Problematic lithologies with elevated sulfur are identified and further geochemical testing is undertaken to understand the AMD potential. Since AMD is not the focus of this paper, there will be limited discussion of the suite of geochemical tests used to characterise PAF material.

Regarding NMD, the chemical assays are examined to determine if there is any chemical enrichment within particular lithologies. Further testing is undertaken if there are significant tonnages of any particular lithology showing enrichment of potential contaminants of concern and where the potential leachability of these contaminants is uncertain.

It is important to understand the likely conditions that waste will be stored onsite and specifically tailored test work may be undertaken if the waste behaviour in a different setting is unknown (Sections 2.3 and 2.4). For example, if a particular lithology has only previously been stored in above water table waste dumps and future plans envisage below water table storage, then it will be important to understand potential geochemical consequences. It will be important to examine the waste leachability in the new setting (with, for example, different redox conditions) and examine the site-specific linkages to any receptors.

\subsection{Extra elemental analysis}

\subsubsection{Extra geochemical analysis of solids}

Selected samples are also assayed for an extended suite of elements, which include $\mathrm{Ag}, \mathrm{B}, \mathrm{Be}, \mathrm{Cd}, \mathrm{F}, \mathrm{Hg}$, $\mathrm{Mo}, \mathrm{Se}, \mathrm{Th}, \mathrm{Tl}$, and $\mathrm{U}$.

Such data can be used to assess element enrichment in a particular stratigraphic unit, noting that this does not necessarily indicate that the elements would be readily mobilised or leached.

\subsubsection{Geochemical analysis of liquids}

Although protocols for static or short-term leach tests vary widely, all tests measure readily soluble constituents of mine wastes and geologic materials. The tests provide a snapshot in time of a material's chemical/physical stability. Test results depend entirely on the current disposition of the sample (e.g. degree of weathering or oxidation prior to sampling, sample handling, and storage regime). For reactive rocks (e.g. material that contains oxidisable sulfur), water-rock interactions often develop over periods of time that are not accessible by short-term testing protocols. Such tests are not therefore suitable 
for deriving information on reaction rates. The results from short-term leach tests can be used to get an initial indication of elements that may become soluble.

Rio Tinto routinely conducts water extracts on a mixture prepared to a 2:1 deionised (DI) water to solid ratio $(w / w)$. Samples selected represent the spatial and volumetric variability of the lithology in the deposit and are not just collected from one location or batch. The crushed portion of the sample $(-4 \mathrm{~mm})$ is typically used in the test, however, the pulverised samples are occasionally used if there are limited options. The water/sample mixture is mixed thoroughly, placed into an automatic tumbler, and left overnight (for approximately 16 hours but this can range from 12 to 24-hours), before the liquor is siphoned off and the $\mathrm{pH}$ and electrical conductivity $(\mathrm{EC})$ measured. The liquor is then filtered $(0.45$ or $0.2 \mu \mathrm{m})$, acidified using concentrated $\mathrm{HNO}_{3}$ before being submitted for multi-element analysis.

Examination of the resulting 2:1 leach extract datasets can give insights to the range of soluble parameters present in waste rock samples and can facilitate identification of possible solubility controls. However, to provide insights to waste dump seepage or pit lake chemistries, scaling or extrapolation will generally be required. This scaling needs to consider contact ratios, reactive surface area, water residence times (kinetically controlled reactions), and adsorbent surface area (sorption control). To better inform scaling, Rio Tinto complements routine 2:1 leach extract tests with modified leach extract testing (Section 2.3).

\subsection{Modified leach extract tests}

A variety of modified leach tests are available and summarised in Table 1. A subset of samples are selected for testing and the suites of tests adopted are focused on obtaining data pertinent to the waste storage options under investigation, and the site-specific conditions that might apply. The overall objectives being to generate datasets suitable to support development of predictive models of geochemical behaviour at field scale. It is important to select the method that most closely simulates the site-specific ambient environment and conditions (e.g. liquid to solid ratio, nature of lixiviant). In addition, selection of a test method has to take into account the anticipated use of the leach test results.

Table 1 Modified leach extract tests (continued next page)

\begin{tabular}{|c|c|c|}
\hline $\begin{array}{l}\text { Leach } \\
\text { method }\end{array}$ & Description & Comment \\
\hline $\begin{array}{l}\text { Mild acid } \\
\text { leach }\end{array}$ & $\begin{array}{l}\text { Leaching using a mild sulfuric } \\
\text { acid solution }\end{array}$ & $\begin{array}{l}\text { Focus is on low sulfur samples, not themselves acid } \\
\text { forming, but could be exposed to acidic contact } \\
\text { water (e.g. non-acid forming (NAF) material to be } \\
\text { utilised within PAF dumps). }\end{array}$ \\
\hline $\begin{array}{l}\text { Alkaline } \\
\text { leaches }\end{array}$ & Leaching using dilute $\mathrm{NaOH}$ & $\begin{array}{l}\text { Relevant for the case where alkaline additives may } \\
\text { have been used in a waste stream. Results represent } \\
\text { conditions in the amended waste itself, or where } \\
\text { seepage from amended waste is in direct contact } \\
\text { with the adjacent environment. }\end{array}$ \\
\hline Saline leach & $\begin{array}{l}\text { Leaching using saline solutions } \\
\text { ( } \mathrm{NaCl} \text {, range of salinities) }\end{array}$ & $\begin{array}{l}\text { Salinities selected to represent groundwater or } \\
\text { brines that could flow into or through waste material. }\end{array}$ \\
\hline $\begin{array}{l}\text { High } \\
\text { temperature } \\
\text { leaching }\end{array}$ & $\begin{array}{l}\text { Leaching with } \mathrm{DI} \text { water at range } \\
\text { of temperatures }\left(20 \text { to } 80^{\circ} \mathrm{C}\right)\end{array}$ & $\begin{array}{l}\text { Relevant for PAF cells containing reactive material. } \\
\text { Focus is column test residues (high levels sulfide } \\
\text { reaction products). }\end{array}$ \\
\hline $\begin{array}{l}\text { Multi-step } \\
\text { leach }\end{array}$ & $\begin{array}{l}\text { 5-10 successive leach cycles } \\
\text { (DI water, every 24-hours) } \\
\text { Bottle roll (L:S } 2: 1 \text { ) or } \\
\text { free-draining column (L:S } \sim 0.4: 1 \text { ) } \\
\text { apparatus }\end{array}$ & $\begin{array}{l}\text { Focus is on low sulfur samples, where leaching is } \\
\text { subject to a possible combination of source term and } \\
\text { solubility controls (see main text for further } \\
\text { explanation of these terms). }\end{array}$ \\
\hline
\end{tabular}




\begin{tabular}{|c|c|c|}
\hline $\begin{array}{l}\text { Leach } \\
\text { method }\end{array}$ & Description & Comment \\
\hline $\begin{array}{l}\text { Low contact } \\
\text { ratio }\end{array}$ & $\begin{array}{l}\text { DI water leach, contact ratio as } \\
\text { low as achievable, L:S 0.3:1 to 1:1. } \\
\text { To address challenges extracting } \\
\text { low water volumes at end of test, } \\
\text { the method involves multiple } \\
\text { bottle rolls and recycling the } \\
\text { leachate. }\end{array}$ & $\begin{array}{l}\text { Wider range of elements may be detectable which } \\
\text { reduces the likelihood of 'false negatives' (e.g. low } \\
\text { leachability may be inferred from 2:1 testing but, for } \\
\text { source term limited contaminants (see main text), a } \\
\text { lower contact ratio could result in elevated } \\
\text { concentrations in seepage that better represent } \\
\text { contact ratios within waste facilities). }\end{array}$ \\
\hline
\end{tabular}

As already mentioned, predictive models often require a degree of scaling or extrapolation to account for changes in key system parameters and/or geochemical conditions.

The importance of contact ratio is illustrated schematically in Figure 6 . The figure also shows expected liquid to solid ratios under field conditions in the Pilbara waste storage facilities and common ratios used in laboratory tests. If a soluble source mineral is present in very low quantities, it may dissolve entirely in the contacting solution without reaching a solubility limit. For such a circumstance, the dissolved concentration is limited by the mass of mineral present (per unit mass rock), the 'source term'. At low contact ratios, due to the low volume of solution per unit mass rock, then relatively high dissolved concentrations may result. In contrast, for a solubility-controlled parameter, the dissolved concentration is constant irrespective of contact ratio (assuming no associated change in solution geochemistry, e.g. pH). For contaminants controlled by solubility, if geochemical conditions in the laboratory are equivalent to field scale, it may be possible to use liquid extract data directly as a measure of seepage or pit lake chemistry.

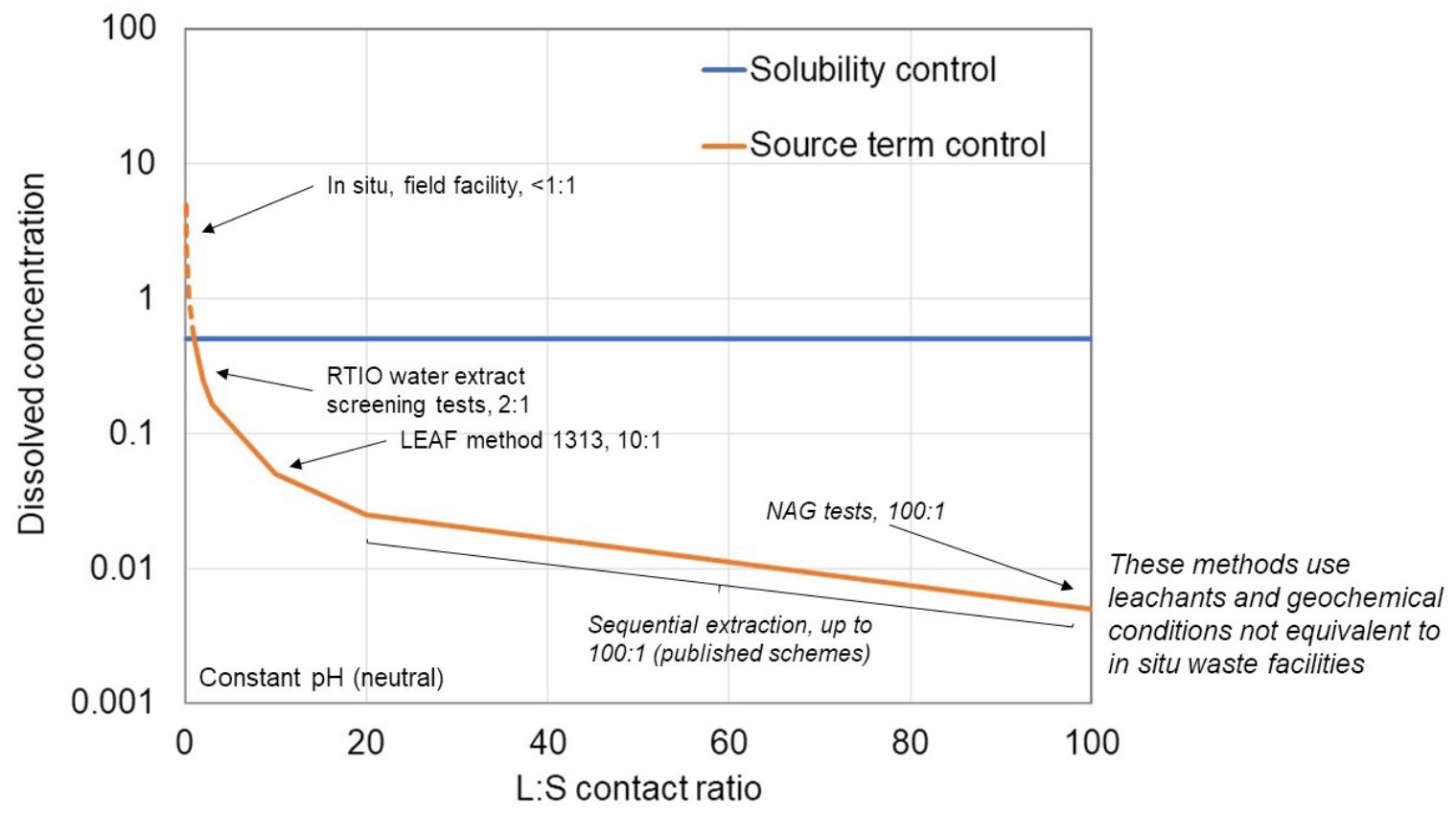

Figure 6 Schematic illustration of varied liquid to solid (L:S) contact ratios and the impact on dissolved concentrations under solubility or source term controls 


\subsection{Advanced test methods}

Advanced test methods are undertaken if there are any unresolved issues or uncertainties from the previous test work. The detailed mineralogical work and sequential extractions are diagnostic tests and used to gain further insight into the proportion of minor or trace element content most vulnerable to mobilisation. Free-draining columns or saturated columns methodologies can generate data suitable for the assessment of reaction rates.

Further details of these tests are presented in Table 2. Geochemical interpretation and/or modelling are important to get full value from the data collected using these advanced methods.

Table 2 Advanced test methods

\begin{tabular}{|c|c|c|}
\hline $\begin{array}{l}\text { Leach } \\
\text { method }\end{array}$ & Description & Comment \\
\hline $\begin{array}{l}\text { Detailed } \\
\text { mineralogical } \\
\text { investigation }\end{array}$ & $\begin{array}{l}\text { Range of advanced surface analytical } \\
\text { techniques are available (TOF-SIM, } \\
\text { QEMSCAN, MLA, LA-ICP-MS, SEM, } \\
\text { ion microprobe, EXAFS etc.)* }\end{array}$ & $\begin{array}{l}\text { Examines the mineral chemistry and degree of } \\
\text { substitution of minor/trace elements in the } \\
\text { mineral lattice. Data on adsorbed species could } \\
\text { be collected. }\end{array}$ \\
\hline $\begin{array}{l}\text { Sequential } \\
\text { extraction }\end{array}$ & $\begin{array}{l}\text { Sample subjected to series of different } \\
\text { leachants, designed to target different } \\
\text { mineral components of the sample } \\
\text { (e.g. Linklater et al. 2014) }\end{array}$ & $\begin{array}{l}\text { Can infer mineralogical hosts for trace } \\
\text { contaminants. Can get an insight into the } \\
\text { elemental content most vulnerable to leaching. } \\
\text { The test conditions are not representative of in } \\
\text { situ waste facilities or lixiviants. }\end{array}$ \\
\hline \multirow[t]{2}{*}{$\begin{array}{l}\text { Free-draining } \\
\text { columns }\end{array}$} & $\begin{array}{l}\text { AMIRA columns and humidity cell } \\
\text { tests. }\end{array}$ & $\begin{array}{l}\text { Designed for application to sulfide-bearing } \\
\text { samples. }\end{array}$ \\
\hline & $\begin{array}{l}\text { Sample is placed in a free-draining } \\
\text { container and rinsed with DI water. } \\
\text { After each rinse cycle, the leachate } \\
\text { collected and analysed. }\end{array}$ & \\
\hline \multirow[t]{2}{*}{$\begin{array}{l}\text { Saturated } \\
\text { columns }\end{array}$} & $\begin{array}{l}\text { Sample material is loaded into a } \\
\text { sealed column (to prevent contact } \\
\text { with atmosphere) and then } \\
\text { saturated with solution. }\end{array}$ & $\begin{array}{l}\text { Designed to determine leaching behaviour under } \\
\text { saturated, anoxic conditions that might be } \\
\text { encountered within submerged backfill. }\end{array}$ \\
\hline & $\begin{array}{l}\text { Porewater volume is replaced } \\
\text { periodically. }\end{array}$ & \\
\hline
\end{tabular}

*ToF-SIMS: time of flight secondary ion mass spectrometry; QEMSCAN: quantitative evaluation of minerals by scanning electron microscopy; MLA: mineral liberation analyse; LA-ICP-MS: laser ablation inductively coupled plasma mass spectrometry; SEM: scanning electron microscopy; EXAFS: extended X-ray absorption fine structure

The LEAF framework (Kosson et al. 2017) combines a series of procedures (static and kinetic) to generate data on leaching as a function of $\mathrm{pH}$, contact ratio, and water residence time. Components of the existing Rio Tinto testing methods, when combined, are analogous to the LEAF methods and there is some degree of overlap. Instead of adopting the LEAF tests directly, Rio Tinto has developed the framework discussed within this paper. This ensured the tests undertaken were more tailored to expected waste materials and site conditions. 


\section{Case studies}

\subsection{Routine analysis: acid and metalliferous drainage risk assessment}

An evaluation of geochemical risks at a proposed new mine site was undertaken during the feasibility study phase. This involved integration of geochemical datasets ( 67,000 total sulfur assays) within the drillhole database (Figure 6). The geochemical dataset was refined to evaluate those drillholes present within the proposed pit shells ( 25,000 total sulfur assays for samples within one of the pit shells), as well as an estimate of likely tonnages and pit wall surface area exposures for the different lithologies. This evaluation identified the potential to expose pyritic black shale and present a relatively high AMD risk. The study team subsequently evaluated if this higher risk material could be avoided and redesigned the pit shell accordingly.

With the avoidance of PAF material, residual geochemical risk could be associated with low sulfur material. The AMD risk assessment addressed this by analysis of drillhole sulfur data at numerous locations and depths across the deposit (Figure 7). The trace element data of the drillholes was analysed to determine elemental enrichment. Enrichment was determined by comparing elemental content against the Global Abundance Index (GAl) (Förstner et al. 1993), which relates the actual concentration to the average crustal abundance on an adjusted log 2 scale (Bowen 1979). The GAI values are truncated to integer increments ( 0 through to 6 ) where a GAl of 0 indicates the element is present at a concentration similar to, or less than, average abundance and a GAl of 6 indicates approximately a 100-fold, or greater, enrichment above average abundance. As a general rule, a GAl of 3 or greater signifies enrichment that warrants further examination, while a GAl of 1 or 2 indicates the element may be elevated. Although an element may be enriched or elevated, it does not necessarily mean that the element would mobilise upon contact with water or when waste rock weathers.

Further testing was undertaken which included acid base accounting ( 200 samples), multi-elemental chemical assays ( $\sim 200$ samples), liquid extracts ( $\sim 50$ samples), low contact ratio leach ( $\sim 4$ samples), multistep leach ( 2 samples), and mild acid leach ( $\sim$ samples). 


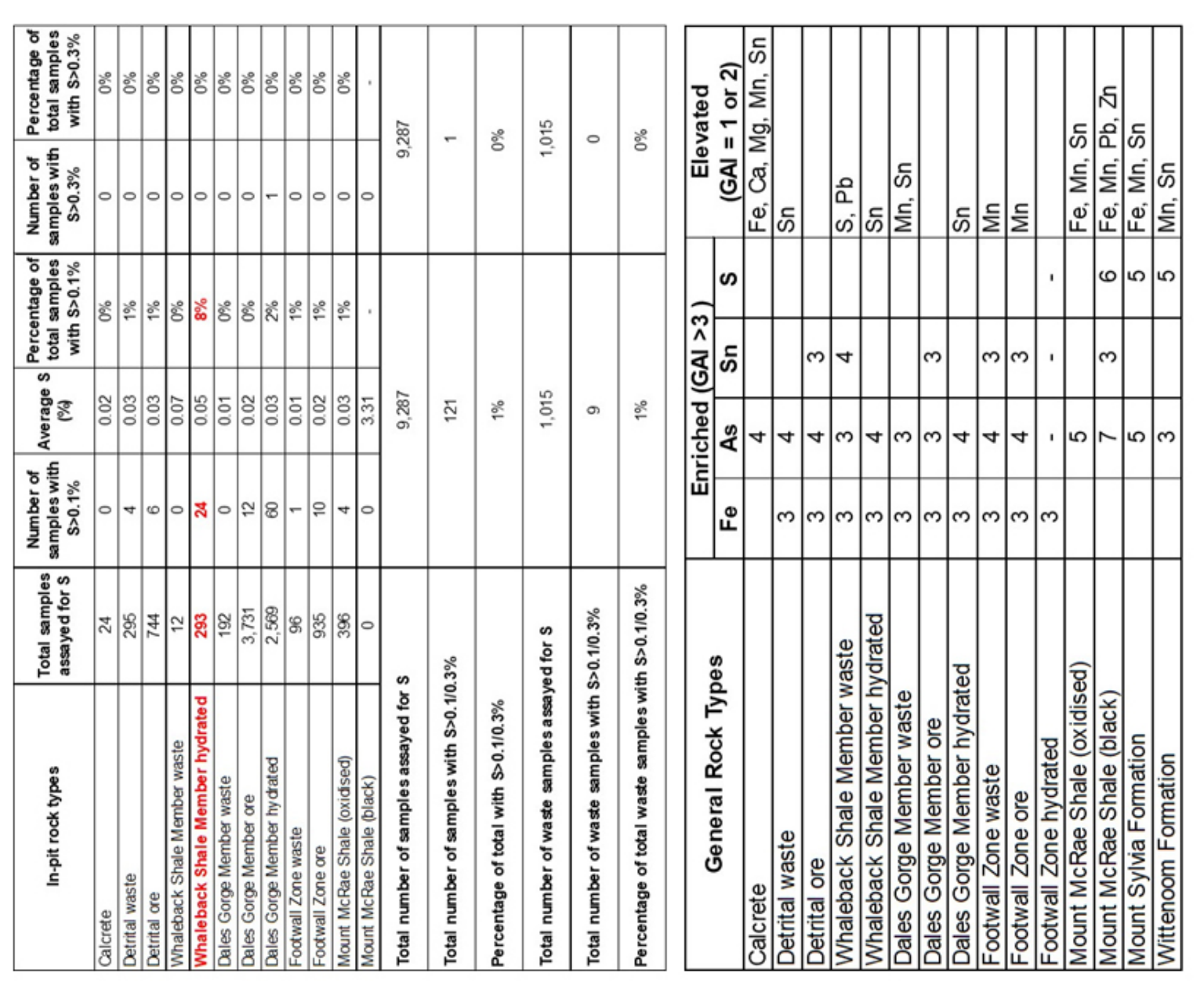

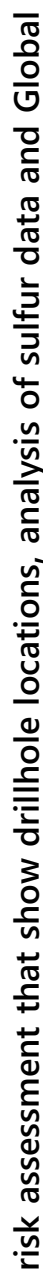
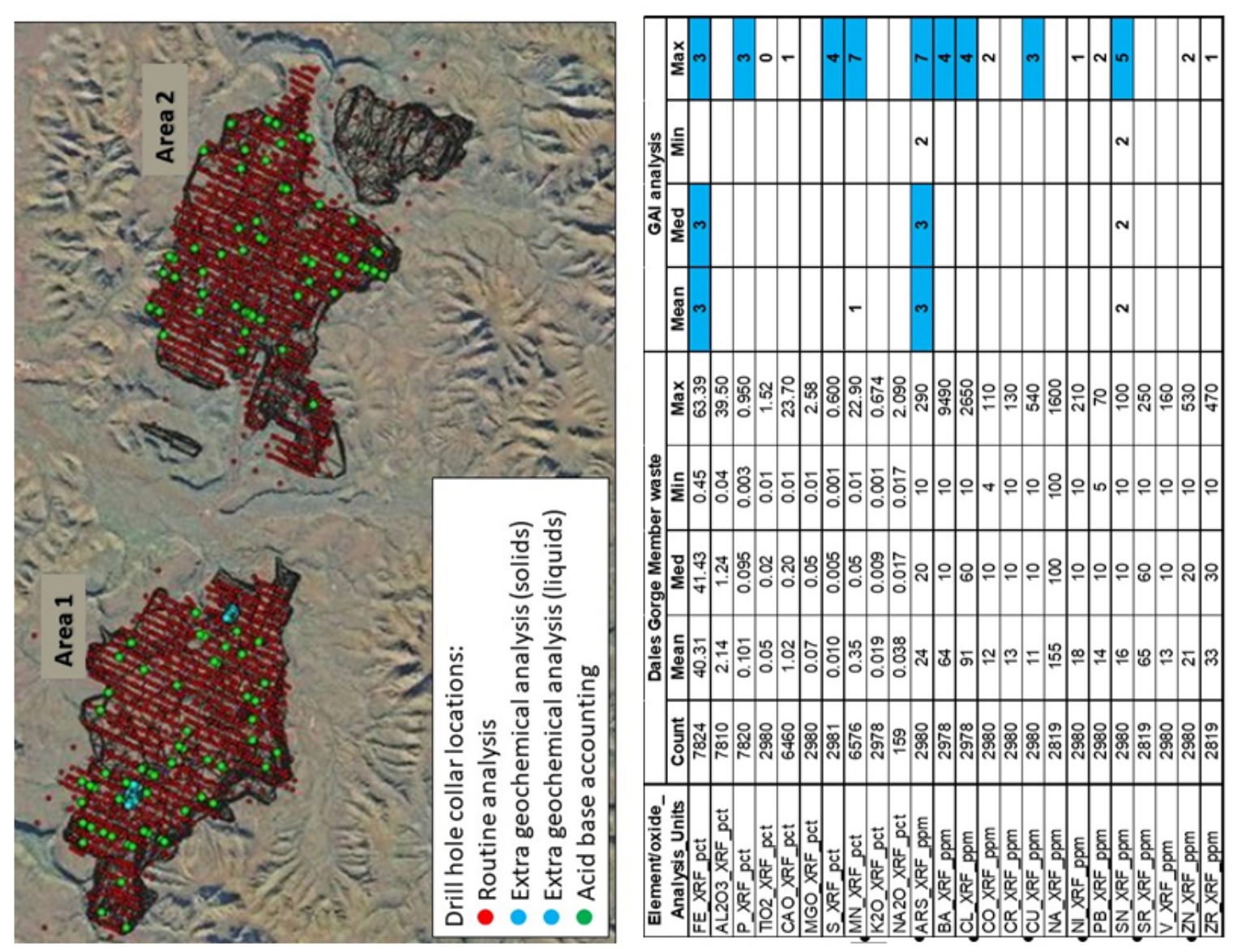

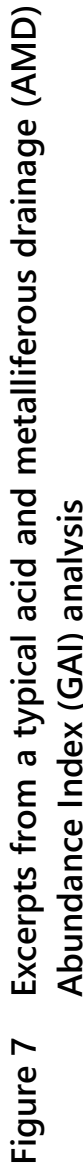




\subsection{Extra elemental analysis: salinity assessment}

$E C$ is the ability of a substance to allow flow of electricity. Pure water strongly resists the passage of an electric current and therefore, has a low EC value. However, salts dissolved in water increase the ability of a solution to conduct an electrical current and therefore, a high EC value indicates a high salinity level.

Liquid extract data (described in the previous section) have been collected from a number of different lithologies across the Pilbara, where EC is typically measured. Most samples represent fresh rock samples (i.e. drillholes or blasted waste samples) that were collected more or less in situ and have had limited exposure to prolonged weathering. The overall EC concentration trends for each lithology are represented in Figure 8. Generally, the EC measurements of in situ samples indicate they are not naturally saline, with the majority of EC measurements below $0.4 \mathrm{dS} / \mathrm{cm}$. There are, however, exceptions:

- Material exposed to prolonged weathering in situ, reflecting the presence of greater quantities of soluble reaction products.

- Material sampled from near-surface locations, possibly influenced by fluctuating water table levels or capillary rise of salts and consequently containing greater concentrations of soluble salts.

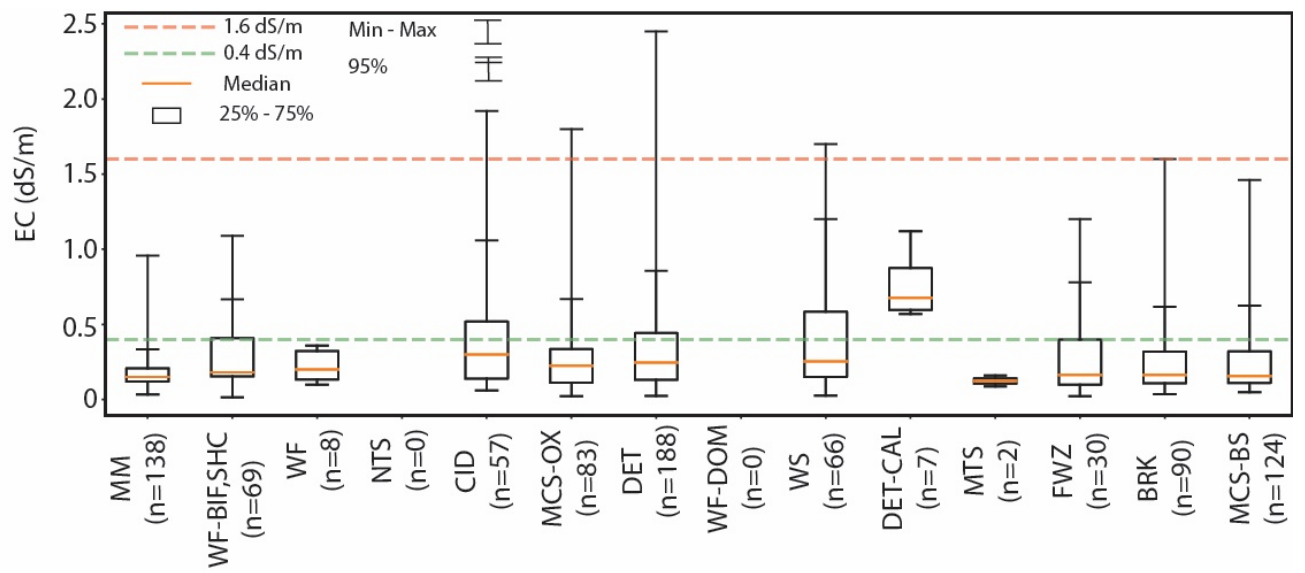

Lithology

Figure 8 Box plots showing the electrical conductivity $(E C)$ values for samples with total sulfur concentrations less than $0.1 \%$ across different lithologies. For abbreviations, refer to Figure 4. All data was extracted using a 2:1 liquid to solid ratio

\subsection{Modified leach extract tests: multi-step leaching}

A geochemical characterisation program was initiated for a deposit where the majority of the samples had low to negligible sulfur and a low potential to generate acid. Most samples were classified as NAF-barren, due to limited ANC potential. Following initial static testing, multi-step leach tests were undertaken on a black Mount McRae Shale sample that was classified using acid base accounting to be uncertain but likely NAF. The total sulfur concentration of the sample was $0.19 \%$ with most sulfur present as sulfate and ANC of $<0.5 \mathrm{~kg} \mathrm{H}_{2} \mathrm{SO}_{4} / \mathrm{t}$. In the multi-step leach test, pre-existing soluble salts are expected to be the main source of sulfates in the sample. Should low-level sulfides be present, there would be insufficient time between rinses for new sulfide oxidation products to accumulate and contribute significantly to the sulfate load.

Results showed a sharp decline in sulfate concentration in the early steps (Figure 9), likely indicating flushing of soluble salts such as gypsum. The cumulative mass of sulfate leached was $0.03 \%$, which accounted for $17 \%$ of the total sulfur content. This would suggest that the sulfur content may be depleted in a relatively short number of leaches. Similarly, the selenium concentration declined with each leach step and could suggest that it is associated with relatively soluble salts that are released as the salt dissolves into solution. 
The static leach test ( 2 parts liquid to 1 part solid) is also shown on Figure 9. At the first time step, similar leachable mass is present, however, a higher dissolved concentration is measured in the low contact ratio test. This indicates source term control of both sulfate and selenium release.

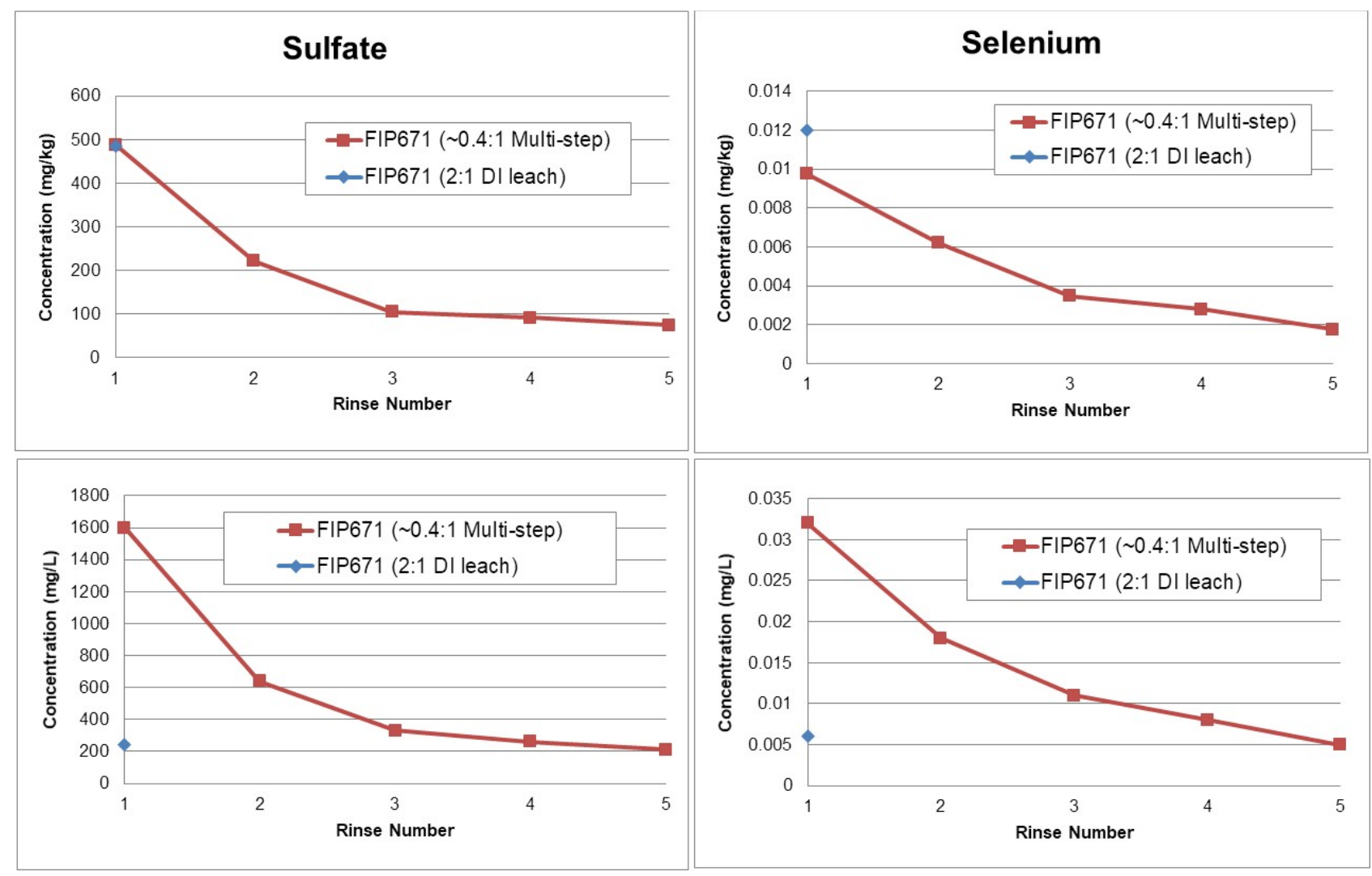

(a)

(b)

Figure 9 Mass (top) and concentration (bottom) of (a) sulfate; (b) selenium

\subsection{Advanced test methods: detailed mineralogical investigation}

Several detailed mineralogical studies have been undertaken to explore mineral and elemental trends. In particular QEMSCAN, ToF-SIMS, LA-ICP-MS, and MLA. The QEMSCAN has been used most commonly and has been undertaken on a variety of high sulfur and low sulfur waste samples.

An example of the QEMSCAN on a low sulfur (0.03\% total sulfur) black shale sample is in Figure 10 . Within this sample, the majority of particles fall within the 20-30 $\mu \mathrm{m}$ particle size range (consistent with the high clay content and dominance of kaolinite and illite/muscovite). Siderite within the sample mainly has $<50 \mu \mathrm{m}$ particle size.

The mineral abundance determined from the QEMSCAN analysis were typically consistent for the major mineral constituents detected by $x$-ray powder diffraction (XRD), with the sample dominated by kaolinite and illite/muscovite. The most noticeable differences are the higher quantities of clay minerals determined by QEMSCAN because these minerals were partially classified as amorphous (30\%) according to XRD analysis. This is largely due to these minerals being associated with the ultra-fine fraction, disordered and/or low crystallinity, therefore being undetected by XRD. Trace minerals identified by QEMSCAN, which were not identified by XRD, include pyrrhotite, alunite, apatite, chlorite, talc, goethite, hematite, quartz, and siderite.

Low-resolution element maps were produced for several elements and the map for aluminium is shown in Figure 11 . Aluminium concentration $(82,600 \mathrm{mg} / \mathrm{kg})$ is associated with nearly all the particles in the sample. This is because aluminium is typically associated with kaolinite, clays, and goethite, which are the dominant minerals. The aluminium associated with clays is mainly associated with expanding clays and chlorite, with 
aluminium likely partitioned with the clay interface. Similarly, the aluminium associated with goethite is likely adsorbed to the goethite surface and/or structurally incorporated within the goethite structure. Highly enriched aluminium is associated with gibbsite particles.

Alunite
Amphibole
Ankerite
Apatite
Background
Calcite
Clay - Chlorite
Clay - Expanding
Clay - Illite/Muscovite
Clay - Talc
Closed Voids
$\square$ Dolomite
Galena
Gibbsite
Goethite
Hematite
Ilmenite
Jarosite
Kaolin
Kaolin-Goethite Intergrowth
Magnetite
Mn Oxides
Others
Pyrite
Pyrrhotite
$\square$ Quartz
Siderite
Ti minerals

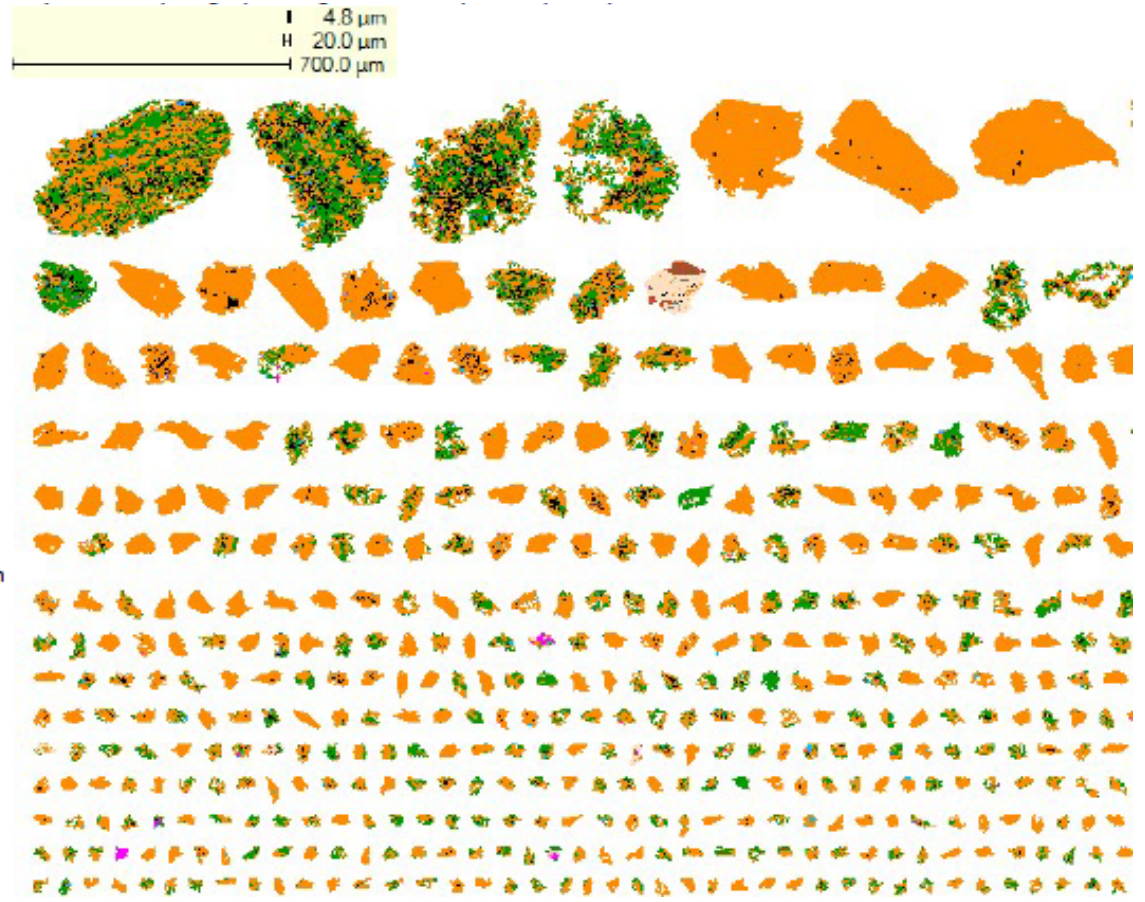

Figure 10 Partial example of the grain size distribution QEMSCAN image of a low sulfur black shale sample

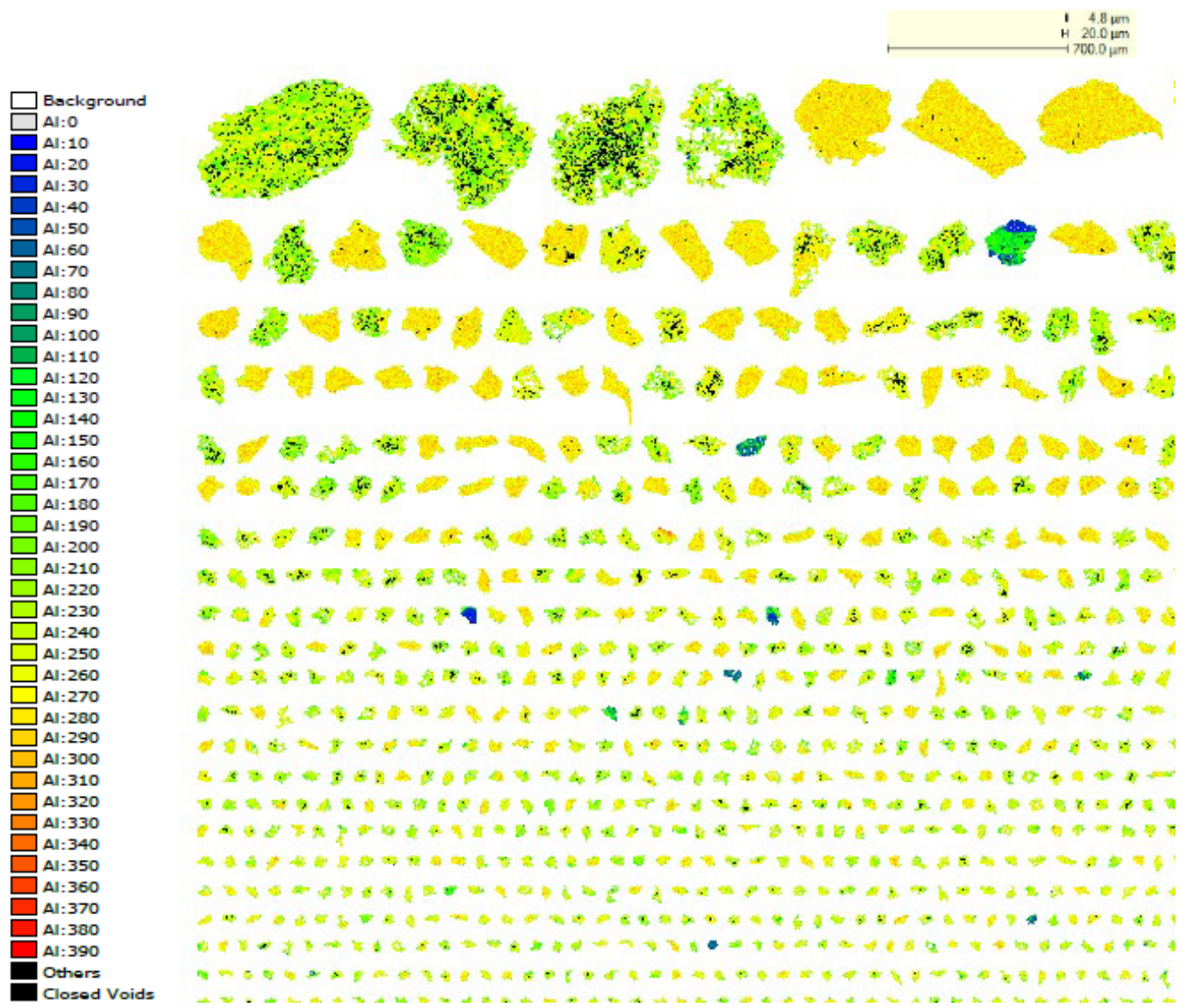

Figure 11 Partial example of the QEMSCAN elemental aluminium intensity maps for the low sulfur black shale sample 


\section{Conclusion}

Rio Tinto adopts a staged and risk-based approach to NMD testing and this enables:

- A great number of samples within a lithology to be analysed giving greater insight to the degree of variability that applies.

- Employment of fit for purpose tests that generate data pertinent to a wide range of geochemical conditions and environmental settings (i.e. applicable to waste rock exposed on walls of a pit lake, waste stored in-pit below the water table, etc.).

The combination of tests can provide appropriate information to assess the risk and, if necessary, enact management measures. The test methods and the interpretation of results become progressively more complex as necessary to resolve uncertainties identified.

\section{Acknowledgement}

The following laboratories have been used to support implementation of the various test methods:

- Modified Leach Extract Test: ALS, SGS, Intertek, SESL Australia.

- Saturated column testing: Intertek, Chemistry Centre.

- Sequential extraction schemes: SESL Australia, Chemistry Centre, Intertek.

- Detailed Mineralogy: RGS Environmental and Blue Minerals Consulting.

\section{References}

Bowen, HJM 1979, Environmental Chemistry of the Elements, Academic Press, London.

Förstner, U, Ahlf, W \& Calmano, W 1993, 'Sediment quality objectives and criteria development in Germany', Water Science \& Technology, vol. 28, pp. 307-316.

Green, R \& Borden, R 2011, 'Geochemical risk assessment process for Rio Tinto's Pilbara iron ore mines', Integrated Waste Management, vol. 1, ch. 19, pp. 365-390.

Kosson, DS, Garrabrants, A, Thorneloe, S, Fagnant, D, Helms, G, Connolly, K \& Rodgers, M 2017, Leaching Environmental Assessment Framework (LEAF) How-To Guide, United States Environmental Protection Agency.

Linklater, CM, Chapman, J, Brown, PL, Green, R \& Leake, S 2014, 'Assessing metal leachability from low sulphur wastes - Sequential extraction methods', in $\mathrm{H}$ Miller \& L Preuss (eds), Proceedings of the Seventh Australian Workshop on Acid Drainage, Adelaide, pp. 325-337.

Stantec Consulting Ltd. 2004, 'Review of Water Quality Issues in Neutral pH Drainage: Examples and Emerging Priorities for the Mining Industry in Canada', The MEND Initiative, http://mend-nedem.org/wp-content/uploads/2013/01/10.1.pdf 
